\title{
High Prevalence of Sternal Foramen: Quantitative, Anatomical Analysis and its Clinical Implications in Acupuncture Practice
}

\author{
Alta Prevalencia del Foramen Esternal: Análisis Cuantitativo y Anatómico \\ y sus Implicancias Clínicas en la Práctica de la Acupuntura
}

\author{
"Marcio A. Babinski; " Fábio A. Rafael; ${ }^{* * *}$ Alisson D. Steil; ${ }^{* *}$ Célio F. Sousa-Rodrigues; \\ ***Emerson A. Sgrott; *Rafael Cisne de Paula \& "Rodrigo M. P. Fernandes
}

BABINSKI, M. A.; RAFAEL, F. A.; STEIL, A. D.; SOUSA-RODRIGUES, C. F.; SGROTT, E. A.; DE PAULA, R. C. \& FERNANDES, R. M. P. High prevalence of sternal foramen: quantitative, anatomical analysis and its clinical implications in acupuncture practice. Int. J. Morphol., 30(3):1042-1049, 2012.

SUMMARY: The aim of our study was to verify the prevalence of the sternal foramen in adult cadavers and dry bones, as well as to determine its exact localization and relation to acupuncture points. One hundred eighty sternums fixed and contained in $10 \%$ formaldehyde solution were examined, of which 100 were dry bones and 80 belonged to adult cadavers. The morphometric measures were expressed in millimeters when measuring the length: 1) from jugular incision to the foramen (JI-F); 2) from sternal angle to the foramen (EA-F); 3) from xiphoid process to the foramen (XP-F). Statistical analysis was performed to compare expected vs obtained foramina frequency, using Fisher's test ( $\mathrm{p} \leq 0.05$ was considered significant). The results showed $16.6 \%$ sternal foramina, significant higher than expected $(\mathrm{p} \leq 0.0248)$. Of the 30 foramina, $53.3 \%$ were found in cadavers, of which one was a woman, and $46.7 \%$ sternums were found in dry bones. Of the cadavers with sternal foramen, 10 foramina were at the 5th sternochondral articulation level and 6 foramina at the 4th sternochondral level. Of the 14 analyzed dry bones, 9 foramina were at the space between the 4th and the 5th costal pit level and 5 foramina were at the 5 th costal pit level. The mean \pm SD $(\mathrm{mm})$ total length of the sternums was $151.8 \pm 34$ and the measures JI-F, EA-F, and XP-F were, respectively, $103.8 \pm 22.1 \mathrm{~mm}, 65.6 \pm 15 \mathrm{~mm}$ and $46.9 \pm 15 \mathrm{~mm}$. Knowledge of this occurrence is important to avoid serious heart injury by needle insertion, especially as this area holds a commonly used acupuncture point and sternal puncture.

KEY WORDS: Gross Anatomy; Cadavers; Anomalies; Sternal Foramen; Acupuncture.

\section{INTRODUCTION}

Human skeletons have many variations that may occasionally necessitate distinction from pathologic changes. The sternum is one of the skeleton parts with frequent variation in appearances on images or autopsy series. In living subjects, sternal variations are frequently detected incidentally on cross-sectional images. Knowledge of radiologic appearances of sternal variations and anomalies is useful so as to not confuse those with pathologic conditions (Yekeler et al., 2006).

The sternal foramen is an anatomical variation that has been well described in the aspects: morphological (McCormick, 1981; McCormick \& Nichols, 1981; Bergman et al., 1988; Cooper et al., 1988; Williams et al., 1996), in clinical acupuncture (Fokin, 2000; Hecker et al., 2005), the risk of inadvertent use of acupuncture point on the foramen
(Bichel, 1989; Chen, 1995; Ernst, 1995; Peuker et al., 1999) and complications of puncture through the foramen (Hasegawa et al., 1991; Halvorsen et al., 1995; Wolochow, 1995; Kataoka, 1997; Kirchgatterer et al., 2000).

Awareness of a sternal foramen is important in acupuncture practice and sternal marrow aspiration because of the danger of heart damage (Fokin). By all means, the particular major risks that acupuncture carries are the risk of traumatic injury to an internal organ, especially the pleura, by needle penetration (Bodner et al., 1983; Gray et al., 1991; Rampes \& James, 1995; Cantan et al., 2003), and the risk of causing bacterial infections in deep structures, though the latter seems to be negligible, probably because the needle tip is too small to carry sufficient inoculum of infected material from the skin (Hoffman, 2001; White, 2006). In this

\footnotetext{
* Department of Morphology, Biomedical Center, Fluminense Federal University, RJ, Brasil.

** Department of Morphology, Biomedical Center, Federal University of Alagoas, AL, Brasil.

**** Department of Anatomy, Health Science Center, Vale do Itajaí University, SC, Brasil.
} 
BABINSKI, M. A.; RAFAEL, F. A.; STEIL, A. D.; SOUSA-RODRIGUES, C. F.; SGROTT, E. A.; DE PAULA, R. C. \& FERNANDES, R. M. P. High prevalence of sternal foramen: quantitative, anatomical analysis and its clinical implications in acupuncture practice. Int. J. Morphol., 30(3):1042-1049, 2012.

way, several authors have collated list of complications caused by or associated with acupuncture (Norheim \& Fonnebo, 1995; Ernst; Ernst \& White, 1997; Rampes \& James; Peuker et al.; White, 2004).

Sternal puncture also has been associated with potentially lethal complications (Ye, 1956; Schiff, 1965; Puschel et al., 1985; Pascali et al., 1987; Bichel; Halvorsen et al.; Peuker et al.; Kirchgatterer et al.; Van-Marum \& TeVelde, 2001).

A few works have verified the relation between the development of cardiac injuries following sternal puncture, or even acupuncture, and the existence of an anatomical anomaly, i.e., the sternal foramen (Hasegawa et al.; Wolochow; Halvorsen et al.; Peuker et al.; Kirchgatterer et al.; Van-Marum \& Te-Velde). Quantitative studies on sternal foramina frequency were performed (Yamamura et al., 1996) in adult patients through roentgenograms (Moore et al., 1988). Therefore, the purpose of our study is to determine the prevalence and exact localization of the sternal foramen in adult cadavers and dry bones.

\section{MATERIAL AND METHOD}

The work complies with the Helsinki Declaration from 1995 (as revised in Edinburgh, 2000). The protocol for the present work has been approved by the Department of Morphology from Biomedical Center at Fluminense Federal University.

One hundred eighty sternums were examined, of which, 100 were dry bones and 80 were from adult cadavers (most of them more than 40 years old), fixed and kept in a $10 \%$ formaldehyde solution, 72 of them belonging to men and 8 belonging to women.

After dissection of the anterior part of the chest wall (Fig. 1), the sternum was exposed in details with the removal of the periosteum on the anterior medium line (Fig. 2A), in $3 \mathrm{~cm}$ width along the whole extension of the sternal body (external and internal surface). The sternocostal articulations and the intercostal spaces were viewed with the aim of relating them to the sternal foramina.

Morphometrical parameters: The morphometric parameters were expressed in millimeters $(\mathrm{mm})$, and through them we obtained the following linear measures(length): 1) from jugular incision to the foramen (JI-F); 2) from the sternal angle (Louis' angle) to the foramen (EA-F); 3) from the xiphoid process to the foramen (XP-F); 4) diameter of the foramen, and 5) thickness of the foramen. All macroscopic measurements were made to the nearest $0.01 \mathrm{~mm}$ using digital calipers, and no distinction was made as to ethnical and sexual dimorphism of the dry bones. In cadavers that showed the existence of sternal foramen (Figs. $1,2 \mathrm{~A}-\mathrm{B})$, a puncture needle was made to verify the correspondence of the sternal foramen with the heart (Fig. 3A-C).

Statistical analysis: For statistical analysis of the frequency of sternal foramen, the software GraphPad Prism 4 statistical software (GraphPad Inc., CA, USA) was used. Fisher's exact test was performed to analyze a contingency Table (Table I), with results showed in Figure 4. The values with $\mathrm{P} \leq 0.05$ was considered significant.

\section{RESULTS}

Of the 180 analyzed sternums from cadavers and skeletons, $30(16.6 \%)$ sternal foramina were found, this result was significant ( $\mathrm{x} \leq 0.0248)$, higher than we expected (Fig. $4)$. Of the 30 foramina found, $16(53,3 \%)$ were observed in cadavers (Fig. 1, 2A), among which 1 was woman (Fig. 2B) and $46.7 \%(14 / 30)$ of sternal foramina were found in dry bones.

The morphometric data (mean $\pm \mathrm{SD}$ ) related to the length of the sternums (cadavers and dry bones) and anatomical location (JI-F, EA-F and XP-F) (Fig.1), were respectively: $151.8 \pm 34 \mathrm{~mm}, 103.8 \pm 22.1 \mathrm{~mm}, 65.6 \pm 15 \mathrm{~mm}$, and $46.9 \pm 15 \mathrm{~mm}$.

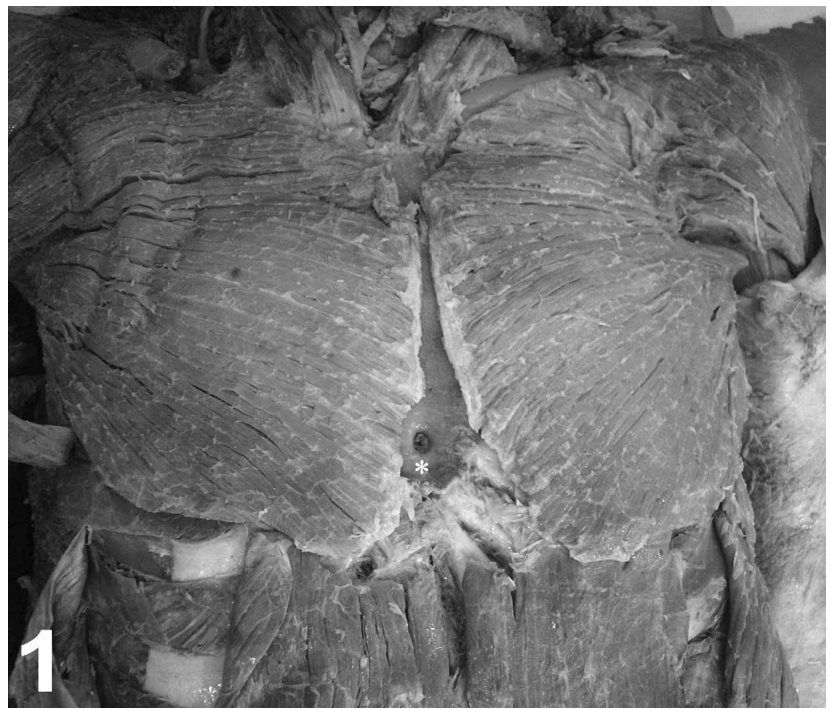

Fig. 1. Photomacrography showing the sternum with a oval sternal foramen well defined (asterisk). 

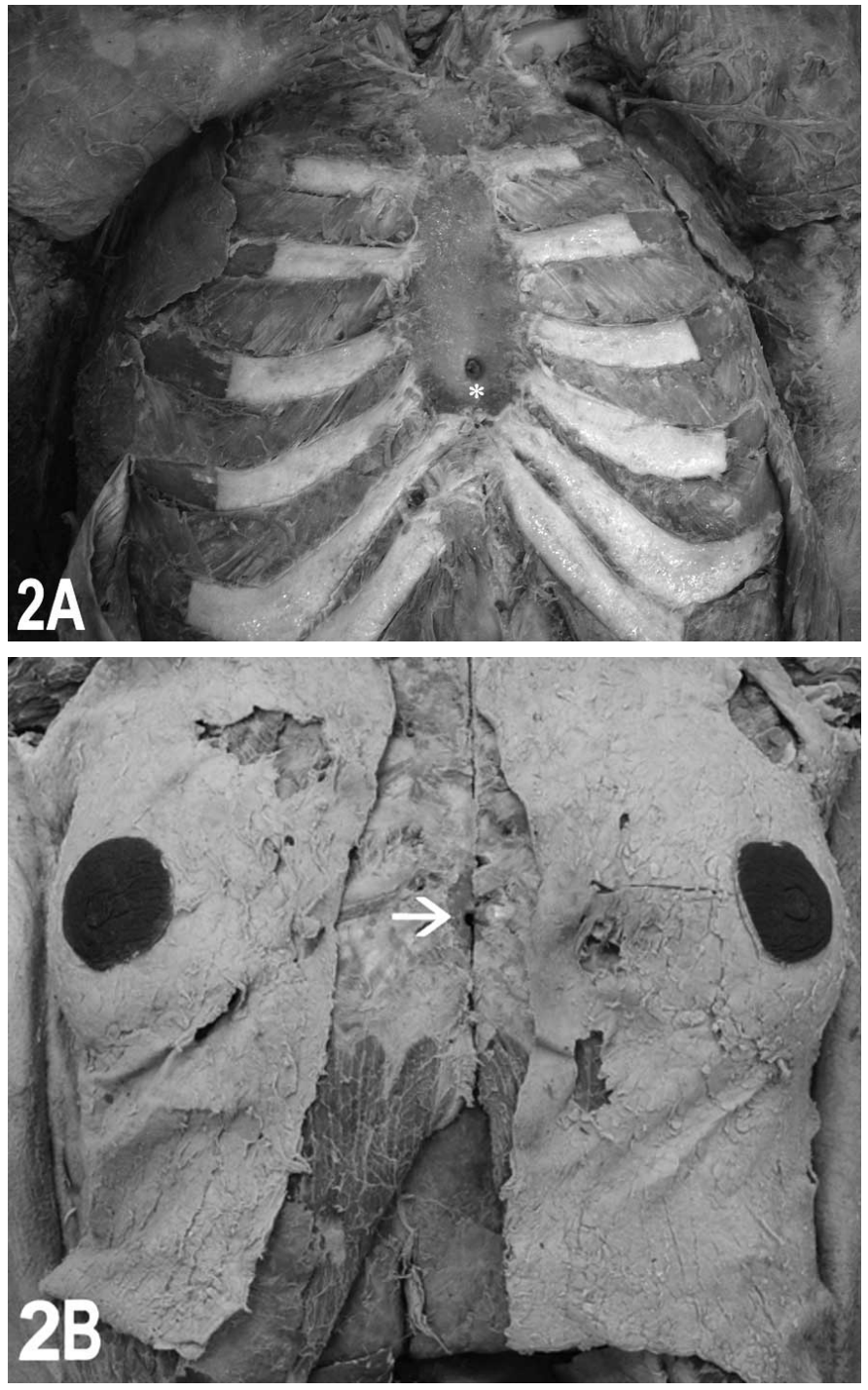

Fig. 2A) A man cadaver with the sternum exposed in details showing an oval sternal foramen (asterisk).

Fig. 2B) A woman cadaver with sternal foramen (arrow).

Fig. 3A) A man cadaver with trans-thoracic penetration (arrow) with punction needle.

Fig. 3B. Check the correspondence of the oval sternal foramen with the heart $(\mathrm{H}) ; \mathrm{L}=$ Liver

Fig. 3C. The damage has occurred (arrow) through trans-thoracic penetration with needle; $\mathrm{L}=$ liver; asterisk= right coronary artery.
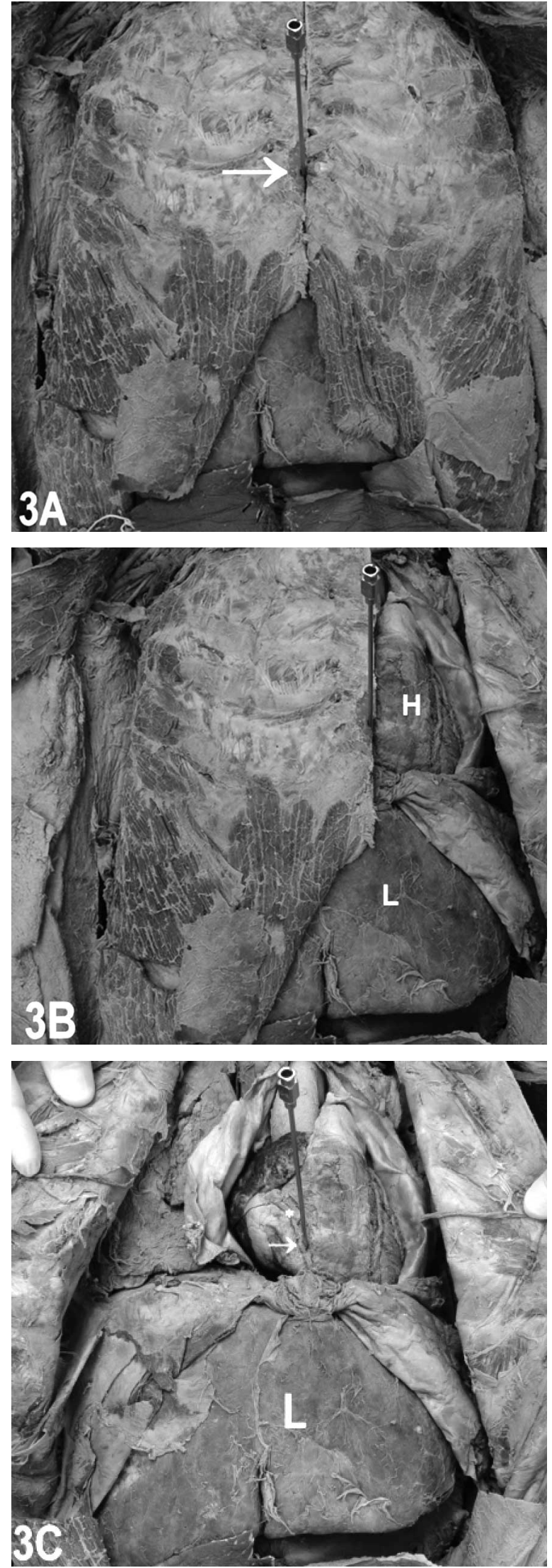


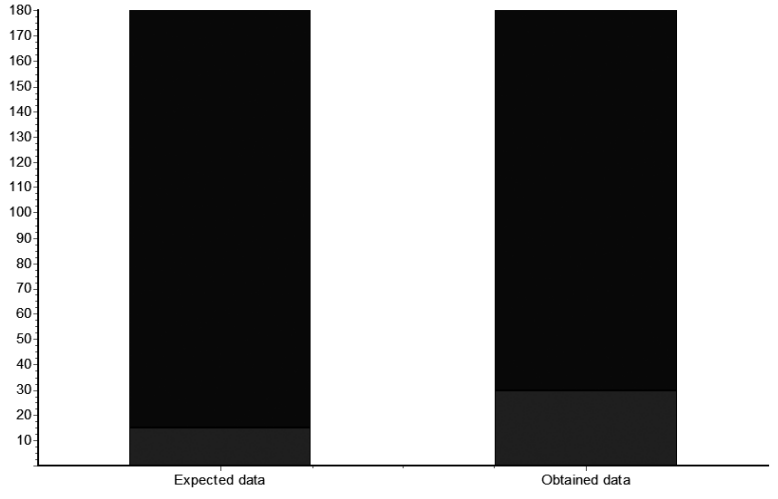

Fig. 4. Analysis between percent data expected (Table I en Results) vs. obtained of the 180 sternums studied.

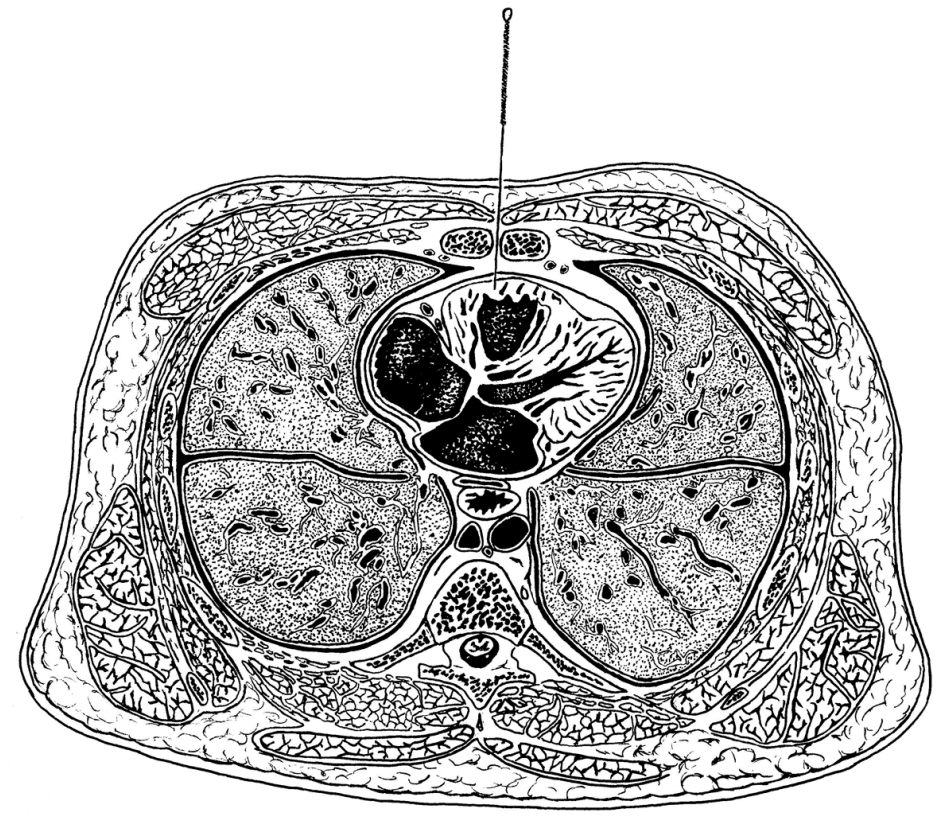

Fig. 5. A schematic drawing of a transversal section of the thorax at the T7 vertebra level representing a perforation of the heart through the presence of the sternal foramen according to figure $3 \mathrm{~B}-\mathrm{C}$

Table I. Analysis between percent data expected (*) vs. obtained of the 180 sternums studied. The $\mathrm{p} \leq 0,05$ was considered significant. *Expected data according to literature (McCormick,1981; Cooper et al., 1988; Peuker et al., 1999; Van-Marum and Te-Velde, 2001; Hecker et al., 2005).

\begin{tabular}{lcc}
\hline Anatomic characteristic & $\begin{array}{c}\text { Expected data } \\
\mathbf{N}(\%)\end{array}$ & $\begin{array}{c}\text { Obtained data } \\
\mathbf{N}(\%)\end{array}$ \\
\hline Normal anatomy of sternum & $165(92)$ & $150(85.4)$ \\
Abnormal anato my: Sternal foramen & $15(8 *)$ & $30(16)$ \\
\hline Total & $180(100)$ & $180(100)$ \\
\hline
\end{tabular}

In all specimens (30) presenting sternal foramen, these were always unique, usually oval or circular in sternal midline location (Figs. 1, 2A). This anomaly was a complete defect with denser connective tissue on the sternal foramen. In cadavers (16), the distance from the skin to the posterior surface of the sternum (thickness) was estimated at $15 \mathrm{~mm}$, with a variation of $12-20 \mathrm{~mm}$.

From the total amount of cadavers with sternal foramen, $62.5 \%(10 / 16)$ were leveled at the 4th sternochondral articulation and 38.5\% (4/16) foramina were leveled at the 5 th articulation (Fig. 2A). Of 14 analyzed dry bones, 64.2\% (9/14) were located at the same level of the space between the 4 th and the 5th costal pits, and 35.8\% (5/14) were leveled at the 5 th costal pit. The mean length of the longitudinal diameter of the foramen was $5.5 \mathrm{~mm}$, varying between $4.0-7.0 \mathrm{~mm}$. The mean cross diameter was $4.5 \mathrm{~mm}$, varying from $3.0-6.5 \mathrm{~mm}$.

In all cadavers that presented the sternal foramen (16), damage to the heart right ventricle by foreign bodies has occurred through trans-thoracic penetration with a needle, the correspondence between the sternal foramen and the heart being thus verified (Figs. 3A-C, 5).

\section{DISCUSSION}

The development and ossification of the sternum is well documented (Ashley, 1956; Pfeiffer, 1956; Riach, 1967; Cooper). During the fetal period, cells migrate from two lateral plates of mesoderm on either side of the anterior chest wall to fuse in the midline, forming the sternum by the $10^{\text {th }}$ fetal week. McCormick \& Nichols reported that ossification begins in manubrium and progresses to mesosternal (body) segments, presenting cranial to caudal development. The manubrium is reported to ossify first, in the $6^{\text {th }}$ fetal month (Kozielec, 1973; Kim et al., 1981; Odita et al., 1985; O'Neal et al., 1998). The mesosternum is reported to ossify in a craniocaudal direction, with ossification occurring first in segment 2 and last in segment 4. Ossification is reported to be present at birth (Kozielec; Kim et al.; Odita et al.; O'Neal et al.).

These congenital anomalies or anatomic variations in the anterior chest wall may involve malignancies, injuries and/or severe traumas (Donnelly et al., 1999; Peuker et al.; Donnelly, 2001; Hecker et al.). Thus, some studies shows that asynchronous ossification of one of the superior four ossification sites may be suggestive of a number of disease processes (Kozielec; Kim et al.; Odita et al.; O’Neal et al.). 
Several studies have stated that sternal segments 1-4 demonstrate ossification centers at birth. The timing of the xiphoid process or sternal segment 5 ossification varies much more, and the xiphoid process may remain non-ossified for years (Ashley; Pfeiffer; Riach; McCormick \& Nichols; Rush et al., 2002). McCormick \& Nichols described the sternal foramen, and Cooper reported the development and morphology of the sternal foramen in this ossification site. Other chest wall anomalies have also been considered (Bergman et al., 1988; McCormick, 1998; Ellis, 1989; Faro et al., 1993; Lancaster et al., 1995; Ontell et al., 1997; Donnelly et al., 1997).

The sternal foramen is a common congenital abnormality (incomplete fusion of the sternal plates). According to Peuker et al., 7 cases of injuries to the heart and the pericardium have been described in scientific literature (Ye; Schiff; Nieda et al., 1973; Cheng, 1991; Hasegawa et al.; Halvorsen et al.; Kataoka), among which 3 were fatal (Ye; Schiff; Halvorsen et al.), two of the fatal cases were caused by lack of awareness of the sternal foramen.

We observed, in our study, that $16.6 \%(30 / 180)$ of total specimens (cadavers and dry bones) presented sternal foramen. This percentual rate anomaly/total specimens is significantly higher than what we expected $(\mathrm{p} \leq 0.0248)$ (Fig. 4) and was previously reported (McCormick; Cooper et al.; Halvorsen et al.). Peuker et al. reported its existence in approximately $5-8 \%$ of the population. Cooper et al., detected a sternal foramen in $6.7 \%$ of all autopsies they performed, and McCormick reported 7.7\%. Although this author (McCormick) had demonstrated 25 sternal foramina in 324 cadaver's studies, Halvorsen et al. and Wolochow mentioned that the sternal foramina are noted in $9-6 \%$ men and $4-3 \%$ women.

Yamamura et al. analyzed 35 Brazilian adult cadavers, of which 27 were men, 8 women, and 5 dry bones. They noticed a higher percentage, $17.5 \%$ (7/40), compared to our results. However, we found sternal foramina in $16.6 \%$ (30/180), where these total of anomalies $53.3 \%(16 / 30)$ were found in cadavers ( 15 men and 1 women) and $46.7 \%$ $(14 / 30)$ were found in dry bones. When compared to the results of Yamamura et al., our results are approximately similar, and this reinforces the hypothesis that the percentual rate of sternal foramina could be higher in the Brazilian population.

Van-Marum \& Te-Velde, pointed out that the prevalence of sternal foramen is estimated at $7 \%$ for the whole population. They could not find any data on the association of prevalence of sternal foramina with complications.
We observed that the sternal foramen presented as a complete defect with denser connective tissue on the foramen, and the distance from the skin to the posterior surface of the sternum presented a variation from $12-20 \mathrm{~mm}$, which is in accordance with Halvorsen et al., and Wolochow, who had reported $13-19 \mathrm{~mm}$. This foramen can vary from a minor periostal indentation to a complete defect, probably resulting from a congenital fusion abnormality (Ashley; McCormick $\&$ Nichols; Van-Marum \& Te-Velde).

Regarding the sternal foramina diameter, our results are consistent to the results reported by McCormick; the sternal foramina were always single, usually from oval to circular shape, at the sternum midline level. The sternal diameters in our study are smaller than those reported by McCormick: longitudinal 4.0-7.0mm (mean 5.5mm) and transversal from $3.0-6.5 \mathrm{~mm}$ (mean $4.5 \mathrm{~mm}$ ).

Schratter et al., (1997) evaluated 100 chest CT scans and distinguished 4 types of these abnormalities, varying from incomplete retraction of the sternal cortex to complete foraminal defects. With reference to the incidence of sternal foramen and its features, they found $8 \%$ of incidence, and $6 \%$ presented a size sufficiently large to represent risks of complications during medical interventions.

The size of the foramen, compared to the caliber of acupuncture needles $(0.20=0.40 \mathrm{~mm})$, is enormous, and the depth of the sternum is relatively small. Thus, the improper and inadvertent use of acupuncture needles (Reichimanis et al., 1976; Nguyen \& Recours-Nguyen, 1984; Chen; Hecker et al.) in the sternal region, at the 4 th sternocostal articulation level or at the $4^{\text {th }}$ parasternal intercostal space, can transfix the sternum (Fig. 3A) and cause an injury in the right ventricle of the heart (Figs. 3C, 5).

Of the total amount of cadavers with sternal foramen, we observed that $62.5 \%(10 / 16)$ were at the $4^{\text {th }}$ sternochondral articulation level, and $38.5 \%(4 / 16)$ at the $5^{\text {th }}$ articulation level. This means that, according to Hirata $e t$ al., (1996), 62.5\% corresponded to the Shangzong acupuncture point (CV 17) and, in $38.5 \%$ corresponded to the Zhongting acupuncture point (CV 16). Of the 14 dry bones analyzed $64.2 \%(9 / 14)$ were at the space between the 4th and the $5^{\text {th }}$ costal pit level and $35.8 \%(5 / 14)$ foramen were at the $5^{\text {th }}$ costal pit level. According to Peuker et al., the sternal foramen is usually located at the level of the fourth intercostal space, i.e., precisely at the acupuncture conception vessel point 17 (CV 17).

For Wolfson et al., (1986) these foramina are typically detected through roentgenograms, whereas to Halvorsen et $a l$. and Peuker et al. it cannot be identified by standard chest 
X-ray films. Using computed tomography (CT) scan, Stark (1985) found this variation in $4.8 \%$ of his sample.

Several risk factors have been considered (Hasegawa et al.; Rampes \& James; Ernst; Peuker et al.; White; Hecker et al.), e.g., damage to the heart and great vessels through the foramina has occurred in transthoracic and abdominal penetration, as well as through the peripheral blood. In our study, damage to the anterior wall of the right heart ventricle through sternal foramen of cadavers was tested by transthoracic penetration with a needle and heart perforation of occurred in all cases (Figs. 3A-C).

Other traumas may occur in the heart, as the rupture of the anterior wall of the right ventricle by sternal puncture already described (Bichel et al.; Van-Marum \& Te-Velde). Bichel et al., collected 34 cases of fatal outcome, and some smaller series were published by others (Puschel et al.; Pascali et al.). The most frequently injury mentioned is puncture below the second intercostal space. Also, in most patients, the heart is below this level during inspiration. Puncture depth should not exceed $4 \mathrm{~mm}$. However, in contrast with these anatomical considerations, there were 34 cases of fatal cardiac tamponade (Van-Marum \& Te-Velde). Pascali et al. suggested that the inexperience of the performing physician was the most relevant risk factor, whereas others related the complication to an inaccurate style guard adjustment.

The usual care observed while performing acupuncture in the conception vessel (VC), specifically in the Zhongting (VC 16) and Shangsong (VC 17) points, has been mentioned in all Traditional Chinese Medicine (TCM) textbooks (Reichimanis et al.; Nguyen \& Recours-Nguyen; Xinnong, 1987; Chen) e.g., angulation of the needle (slightly at $45^{\circ}$ ), depth of insertion (usually $0.3-0.5 \mathrm{Cun}=\mathrm{a}$ Chinese measure equivalent to $1 \mathrm{inch}$ ). Once these requirements are met, the consequent cardiac puncture will be avoided (Fig. 5), which could cause a cardiac tamponade (Hasegawa et al.; Halvorsen et al.; Wolochow; Yamamura et al.; Van-Marum \& Te-Velde).

A large portion of complications and accidents that have been reported could have easily been avoided if the therapists had a basic knowledge in anatomy, and had considered the basic principles of any invasive form of therapy. In other words, these incidents can be attributed to incorrect application of the procedure during diagnosis and therapy. Still, the issue cannot be dismissed with the simple notion that acupuncture would probably be free of side effects if performed by a physician. It doesn't matter whether side effects are due to the procedure or its application. It is the duty of educational organizations and their teachers to point out these potential risks. In connection with the quality assurance required in acupuncture, it is necessary to conduct not only scientifically correct studies on its effects and effectiveness, but also conduct reliable studies on its adverse events and complications (Hecker et al., 2005).

\section{CONCLUSION.}

Our results indicate that the sternal foramina is frequent in $16.6 \%$ of Brazilians cadavers and these percentages were significantly higher than expected of literature. In addition, the knowledge of this occurrence is important to avoid serious heart injury by needle insertion, especially since this area holds a commonly used acupuncture point and sternal puncture. This anatomical curiosity should be kept in mind by clinicians and resident medical students that may manipulate this anatomical area.

ACKNOWLEDGMENTS: The authors thank Mr. Rafael L.R. Maciel for technical support in schematic drawing.

BABINSKI, M. A.; RAFAEL, F. A.; STEIL, A. D.; SOUSA-RODRIGUES, C. F.; SGROTT, E. A.; DE PAULA, R. C. \& FERNANDES, R. M. P. Alta prevalencia de foramen esternal: El análisis cuantitativo, anatómico y sus implicancias clínicas en la práctica de la acupuntura. Int. J. Morphol., 30(3):1042-1049, 2012.

RESUMEN: El objetivo del estudio fue verificar la prevalencia del foramen esternal en cadáveres adultos y huesos secos, así como, determinar su localización y su relación con los puntos de acupuntura. Fueron examinados 180 esternones fijados en solución de formol al 10\%, 100 eran huesos secos y 80 pertenecían a cadáveres de individuos adultos. Las medidas morfométricas se expresaron en milímetros, efectuándose las siguientes mediciones: 1) desde la incisura yugular al foramen; 2) desde el ángulo esternal al foramen y 3) desde el proceso xifoides hasta al foramen. El análisis estadístico permitió comparar la frecuencia de los forámenes, usando el test de Fisher ( $\mathrm{p} \leq 0,05$ ). Los resultados mostraron la presencia del foramen esternal en 16,6\% de los casos, siendo significativamente mayor a lo esperado ( $\mathrm{p} \leq 0,0248$ ). De los 30 forámenes, el 53,3\% se encontró en cadáveres y en el 46,7\% en los huesos secos. De los cadáveres con foramen esternal, 10 forámenes se encontraban a nivel de la $5^{\text {a }}$ articulación esternocondral y 6 a nivel de la $4^{\mathrm{a}}$ articulación esternocondral. De los 14 forámenes de los huesos secos, 9 forámenes se encontraban entre entre el 4 y el $5^{\circ}$ espacio intercostal y 5 se localizaban a nivel del $5^{\text {a }}$ articulación. La longitud total del esternón fue $151,8 \mathrm{~mm} \pm 34$ y las medidas desde la incisura yugular al foramen, desde el ángulo esternal al foramen y desde el proceso xifoides hasta al foramen fueron, 103,8 \pm $22,1 \mathrm{~mm}, 65,6 \pm 15 \mathrm{~mm}$ y 46,9 $\pm 15 \mathrm{~mm}$, respectivamente. El conocimiento de este hecho es importante para evitar la lesión cardiaca grave por la inserción de agujas, ya que esta zona tiene un punto de acupuntura de uso común en la punción esternal.

PALABRAS CLAVE: Anatomía; Cadáveres; Variaciones; Foramen esternal; Acupuntura. 
BABINSKI, M. A.; RAFAEL, F. A.; STEIL, A. D.; SOUSA-RODRIGUES, C. F.; SGROTT, E. A.; DE PAULA, R. C. \& FERNANDES, R. M. P. High prevalence of sternal foramen: quantitative, anatomical analysis and its clinical implications in acupuncture practice. Int. J. Morphol., 30(3):1042-1049, 2012.

\section{REFERENCES}

Ashley, G. T. The relationship between the pattern of ossification and the definitive shape of the mesosternum in man. J. Anat., 90: 87-105, 1956.

Bichel, J. Serious complications of sternal puncture. Ugeskr. Laeger., 151: 442-4,1989.

Bergman, R. A.; Thompson, S. A.; Afifi, A. K. \& Saadeh, F. A. Compendium of Human Anatomic Variation: Catalog, Atlas and World Literature. Baltimore, Urban \& Schwarzenberg, 1988.

Bodner, G.; Topilsky, M. \& Greif, J. Pneumothorax as a complication of acupuncture in the treatment of bronchial asthma. Ann. Allergy, 51(3): 401-3, 1983.

Cantan, R.; Milesi-Defrance, N.; Hardenberg, K.; Vernet, M.; Messant, I. \& Freysz, M. Bilateral pneumothorax and tamponade after acupuncture. Press. Med., 32(7): 311-2, 2003.

Cheng, T. O. Pericardial effusion from self-inserted needle in the heart. Eur. Heart. J., 12(8):958, 1991.

Chen, E. Cross sectional Anatomy of points. Churchill Livingstone, Edinburgh, 1995.

Cooper, P. D.; Stewart, J. H. \& McCormick, W. F. Development and morphology of the sternal foramen. Am. J. Forensic. Med. Pathol., 9(4):342-7, 1988.

Donnelly, L. F.; Taylor, C. N. R,; Emery, K. H. \& Brody, A. S. Asymptomatic, palpable, anterior chest wall lesions in children: is cross-sectional imaging necessary? Radiology, 202:829-31, 1997.

Donnelly, L. F.; Frush, D. P.; Foss, J. N.; O'Hara, S. M. \& Bisset, G. S.3rd. Anterior chest wall: frequency of anatomic variations in children. Radiology, 212(3):837-40, 1999.

Donnelly, L. F. Use of Three-Dimensional Reconstructed Helical CT Images in Recognition and Communication of Chest Wall Anomalies in Children. A.J.R., 177:441-5, 2001.

Ellis, D. G. Chest wall deformities in children. Pediatr. Ann., 18: 161-5, 1989.

Ernst, E. The risks of acupuncture. Int. J. Risk. Safety Med., 6: 179-86, 1995.

Ernst, E. \& White A Lile-threatening adverse reactions of acupuncture? a system- atic review. Pain, 71:123-6, 1997.

Faro, S. H.; Mahroubi, S. \& Ortega, W. CT diagnosis of rib anomalies, tumors, and infection in children. Clin. Imaging., 17:1-7,1993.
Fokin, A. A. Cleft sternum and sternal foramen. Chest Surg. Clin. North. Am., 10: 261-76, 2000.

Gray, R.; Maharajh, G. S. \& Hyland, R. Pneumothorax resulting from acupuncture. Can. Assoc. Radiol. J., 42(2):139-40, 1991.

Hasegawa, J.; Noguchi, N.; Yamasaki, J.; Kotake, H.; Mashiba, H.; Sasaki, S.; et al., Delayed cardiac tamponade and hemothorax induced by an acupuncture needle. Cardiology, 78(1):58-63, 1991.

Halvorsen, T. B.; Anda, S. S.; Naess, A. B. \& Levang, O. W. Fatal cardiac tamponade after acupuncture through congenital sternal foramen [letter]. Lancet, 345:1175, 1995.

Hecker, H. U.; Steveling, A.; Peuker, E. T. \& Kastner, J. Practice of Acupuncture. Thieme, Stuttgart, 2005.

Hirata, L. C. G.; Yamamura, Y.; Cricenti, S. V. \& Esper, R. S. Localização anatômica do ponto VC-17 (Shanzhong) do canal Ren Mai. Rev. Paul. Acupunt., 2(1):25-8, 1996.

Hoffman, P. Skin disinfection and acupuncture. Acupunct. Med., 19(2):112-6, 2001.

Kataoka, H. Cardiac tamponade caused by penetration of an acupuncture needle into the right ventricle. J. Thorac. Cardiovasc. Surg., 114:674-6, 1997.

Kirchgatterer, A.; Schwarz, D.; Hoeller, E.; Punzengruber, C.; Hartl, P. \& Eber, B. Cardiac tamponade following acupuncture. Chest, 117(5 ):1510-1, 2000.

Kim, O. H.; Gooding, C. A. Delayed sternal ossification in infants with congenital heart disease. Pediatr. Radiol., 10:21923,1981 .

Kozielec, T. A. roentgenometric study of the process of ossification of the human sternum. Folia Morph., 32:12548, 1973.

Lancaster, L.; McIlhenny, J.; Rodgers, B.; Alford, B. Radiographic findings after pectus excavatum repair. Pediatr. Radiol., 25: 452-4, 1995.

McCormick, W. F. Sternal foramena in man. Am. J. Forensic Med. Pathol., 2(3):249-52, 1981.

McCormick, W. F. \& Nichols, M. M. Formation and maturation of the human sternum. I. Fetal period. Am. J. Forensic Med. Pathol., 2(4):323-8, 1981.

McCormick, W. F.; Flournoy, L. E.; Rogers, N.L. \& Ross, A.H. An unusual case of multiple mesosternal foramina. J. Forensic Sci., 43(3):706-7, 1998. 
BABINSKI, M. A.; RAFAEL, F. A.; STEIL, A. D.; SOUSA-RODRIGUES, C. F.; SGROTT, E. A.; DE PAULA, R. C. \& FERNANDES, R. M. P. High prevalence of sternal foramen: quantitative, anatomical analysis and its clinical implications in acupuncture practice. Int. J. Morphol., 30(3):1042-1049, 2012.

Moore, M. K.; Stewart, J. H. \& McCormick, W. F. Anomalies of the human chest plate area. Radiographic findings in a large autopsy population. Am. J. Forensic. Med. Pathol., 9(4):348$54,1988$.

Nieda, S.; Abe, T.; Kuribayashi, R.; Sato, M. \& Abe, S. Case of a cardiac injury resulting from acupuncture. Kyobu. Geka., 26(12): 881-3, 1973.

Nguyen, V. N.; Recours-Nguyen, C. Médicine Traditionnelle Chinoise. Ed. N.V.N.: Marseille, 1984.

Norheim, A. J. \& Fonnebo V Adverse effects of acupuncture. Lancet, 345:1576, 1995.

Odita, J. C.; Okolo, A. A. \& Omene, J. A. Sternal ossification in normal newborn infants. Pediatr. Radiol., 15:165-7,1985.

O’Neal, M. L.; Dwornik, J. J.; Ganey, T. M. \& Ogden, J. A. Postnatal development of the human sternum. J. Pediatr. Orthop., 18: 398-405, 1998.

Ontell, F. K.; Moore, E. H.; Shepard, J. A. \& Shelton, D. K. The costal cartilage in health and disease. RadioGraphics, 17:5717, 1997.

Pascali, V. L.; Lazzaro, P. \& Fiori, A. Is sternal bone marrow needle biopsy still a hazardous technique? Report of three further fatal cases. Am. J. Forensic Med. Pathol., 8:42-4, 1987.

Peuker, E. T.; White, A.; Ernst, E.; Pera, F. \& Filler, T. J. Traumatic complications of acupuncture. Arch. Fam. Med., 8:553-8, 1999.

Pfeiffer, K. Variations and anomalies of the sternum and indications concerning their development. Fortschr. Geb Rontgenstr. Nuklearmed., 85(6):663-71, 1956.

Puschel, K.; Mattern, R.; Mittmeyer, H. J. \& Schneider, V. Errors and hazards: fatalities through sternal puncture. Dtsch. Med. Wochenschr., 110:1611-3, 1985.

Rampes, H. \& James, R. Complications of acupuncture. Acupunct. Med., 13:26-33, 1995.

Reichimanis, M.; Marino, A. A. \& Becker, R.O.D.C. Conductance variations at acupuncture loci. Am. J. Chin. Med., 4:69-72, 1976.

Riach, I.C.F. Ossification in the sternum as a means of assessing skeletal age. J. Clin. Pathol., 20:589-90, 1967.

Rush, W. J.; Donnelly, L. F.; Brody, A. S.; Anton, C. G. \& Poe, S.A. "Missing" Sternal Ossification Center: Potential Mimicker of Disease in Young Children. Radiology, 224:120-3, 2002.

Schratter, M.; Bijak, M.; Nissel, H.; Gruber, I. \& Schratter-Sehn, A.U. Foramen sternale: Kleine Anomalie-grobe Relevanz. Fortsehr. Rontgenstr., 166:69-71, 1997.
Stark, P. Midline sternal loramen: CT demonstration. J. Comp. Assist. Tomogr., 9:489-90, 1985.

Schiff, A. F. A fatality due to acupuncture. Med. Times, 93:630-1, 1965.

Van-Marum, R .J. \& Te-Velde, L. Cardiac tamponade following sternal puncture in two patients. The Netherlands J. Med., 59: 39-40, 2001.

Xinnong, C. Chinese Acupuncture and Moxibuston. Forein Languages Press. Beijing., 1987.

Williams, P.; Warwick, R.; Dyson, M. \& Bannister, L.H. Gray: Anatomia. $37^{\text {th }}$ ed. Guanabara Koogan, Rio de Janeiro, 1996.

White, A. The safety of acupuncture - evidence from the UK. Acupunct. Med., 24(Suppl):S53-57, 2006.

White, A. A cumulative review of the range and incidence of significant adverse events associated with acupuncture. Acupunct. Med., 22(3):122-33, 2004.

Wolfson, R. H.; Moore, E. E. \& Van-Way, C.W. III Delayed staple penetration of the heart: Transthoracic migration with late tamponade. J. Trauma., 26:293-4, 1986.

Wolochow, M. S. Fatal cardiac tamponade through congenital sternal foramen. Lancet, 346, 442, 1995.

Yamamura, Y.; Esper, R. S. \& Cricenti, S.V. Forames esternais e os pontos de acupuntura VC-17 (Shanzhong) e VC-16 (Zhongting) do canal curioso Ren Mai. Rev. Paulista Acupunt., 2(1):29-33, 1996.

Ye, T. A death from cardiac rupture caused by acupuncture on Jiu Wei (CV15). J. Tradit. Chin. Med., 8:433-4, 1956.

Yekeler, E.; Tunaci, M.; Tunaci, A.; Dursun, M. \& Acunas, G. Frequency of Sternal Variations and Anomalies Evaluated by MDCT. A.J.R., 186:956-60, 2006.

Correspondence to:

Prof. Dr. Marcio Antonio Babinski

Departamento de Morfologia

Instituto Biomédico - UFF

Rua: Prof. Ernani Melo 101, (Anatomia)

São Domingos

24210-150

Niterói (RJ)

BRASIL

Phone/Fax: + 552126292336

Email: mababinski@gmail.com

Received: 28-02-2012

Accepted: 02-04-2012 